\title{
PEMANFAATAN LIMBAH HIDROPONIK SELADA KERITING (Lactuca Sativa L.), ROMAINE (Lactuca Sativa Var. Romana), LOLLOROSA (Lactuca Sativa Var. Lollrosa) DALAM PEMBUATAN ES KRIM
}

\author{
Oleh : \\ Nurdi Ibnu Wibowo*) \\ M. Naufal Amar Siddik**) \\ Email : nurdiiso@yahoo.co.id
}

\begin{abstract}
ABSTRAK
Selada (Lactuca sativa $L$ ) merupakan salah satu sayuran populer yang memiliki nilai ekonomi tinggi, dan memiliki banyak kandungan gizi sehingga tanaman ini berpotensi untuk terus di budidayakan. Dalam budidaya tanaman hidroponik selada keriting, romaine, dan lollorosa banyak terdapat hasil trimming dan tanaman yang tidak sesuai dengan kebutuhan pasar sehingga menghasilkan limbah hasil pertanian yang menimbulkan maslah bagi lingkungan sekitar. Banyaknya manfaat yang terkandung dalam tanaman selada sehingga dapat dimanfaatkan menjadi pangan fungsional dalam pembuatan es krim. Rancangan penelitian dibuat menjadi 5 sampel dengan formulasi yang berbeda dari setiap sampelnya. Respon dari panelis didapatkan dengan melakukan uji hedonik dengan melibatkan 24 panelis biasa dan 1 panelis ahli dan dianalisis menggunakan Response Surface Methods (RSM). Hasil penelitia menunjukan bahwa formula yang berbeda dari setiap sampel berpengaruh terhadap warna, rasa, aroma, dan tekstur es krim selada keriting, romaine, lollorosa. Sampel dari F1 merupakan sampel terbaik dari segi warna. Sampel F1 merupakan sampel terbaik dari rasa. Sampel F1 merupakan sampel terbaik dari segi aroma, dan sampel F1 juga merupakan sampel terbaik dari segi tekstur. Sampel F1 merupakan sampel terbaik dari kelima sampel dengan formulasi selada keriting 70\%, romaine 15\%, Lollorosa 15\%.(188 kalimat).
\end{abstract}

Kata kunci : Selada keriting, Romaine, Lollorosa, Es krim, Pangan fungsional.

\section{ABSTRACT}

Lettuce (Lactuca sativa L) is one of the popular vegetables that has high economic value, and has a lot of nutritional content so that this plant has the potential to continue to be cultivated. In bydroponic cultivation of curly lettuce, romaine, and lollorosa there are many trimming results and plants that are not in accordance with market needs, resulting in agricultural waste that causes problems for the surrounding environment. The many benefits contained in the lettuce plant so that it can be used as a functional food in making ice cream. The research design was made into 5 samples with different formulations from each sample. The response from the panelists was obtained by conducting a hedonic test involving 24 regular panelists and 1 expert panelist and analyzed using Response Surface Methods (RSM). The results showed that the different formulas of each sample affected the color, taste, aroma, and texture of curly lettuce, romaine, lollorosa ice cream. The sample from F1 is the best sample in terms of color. Sample F1 is the best sample of taste. Sample F1 is the best sample in terms of aroma, and sample F1 is also the best sample in terms of texture. Sample F1 is the best sample of the five samples with the formulation of curly lettuce $70 \%$, romaine 15\%, Lollorosa $15 \%$.

Keywords: Curly lettuce, Romaine, Lollorosa, Ice cream, Functional food.

*)Dosen Widyaiswara Madya PPPPTK Pertanian/BBPPMPV Pertanian.

**)Alumni Fakultas Sains Terapan UNSUR.

PEMANFAATAN LIMBAH HIDROPONIK

NURDI IBNU WIBOWO

SELADA KERITING (Lactuca Sativa L.),

ROMAINE (Lactuca Sativa Var. Romana),

LOLLOROSA (Lactuca Sativa Var. Lollrosa)

DALAM PEMBUATAN ES KRIM

dan M. NAUFAL AMAR SIDDIK 


\section{PENDAHULUAN}

Indonesia merupakan salah satu negara agraris artinya sektor pertanian di Indonesia memiliki peranan penting dari keseluruhan perekonomian nasional (Tunjung, 2010). Sistem hidroponik merupakan salah satu cara budidaya yang sudah mulai digemari di era modern seperti sekarang ini, karena mudah dalam perawatan dan dalam melakukan aktivitas pertaniannya dijalankan dengan menggunakan air sebagai medium untuk menggantikan tanah (Roidah, 2014). Tanaman hortikultura merupakan tanaman yang paling banyak dibudidayakan pada sistem hidroponik.

Hortikultura merupakan salah satu produk yang melimpah yang dihasilkan oleh masyarakat Indonesia. Salah satu subsektor yang berperan meningkatkan ketahanan pangan di Indonesia adalah subsektor hortikultura. Menurut BPS (2014), Jawa Barat merupakan salah satu Provinsi yang menyumbang produksi sayuran terbesar di Indonesia dengan produksi pertahun yaitu 2,5 juta ton. Produk hortikultura yang sering dijumpai oleh masyarakat adalah sayuran, salah satu jenis sayuran yang memiliki kandungan gizi yang baik adalah selada (Dian et al., 2017).

Selada (Lactuca Sativa L.) merupakan sayuran popular karena memiliki warna, tekstur serta aroma yang menyegarkan tampilan makanan dan salah satu sayuran yang memiliki nilai ekonomi yang tinggi, kandungan gizi yang banyak membuat tanaman ini berpotensi untuk terus dibudidayakan. Selada memiliki banyak kandungan gizi dan vitamin pada tiap $100 \mathrm{~g}$ seperti: kalori $15,00 \mathrm{kal}$, protein 1,20 g, lemak 0,20 g, karbohidrat 2,90 g, kalsium 22,00 $\mathrm{mg}$, fosfor 25,00 g, zat besi (Fe) 0,50 mg, vitamin A 540,00 S.I, vitamin B1 0,04 mg, vitamin C 8,00 mg, air 94,80 g (Sastradihardja, 2011)

Manfaat tanaman selada bagi tubuh yaitu dapat membantu pembentukan sel darah putih dan sel darah merah dalam susunan sumsum tulang, mengurangi resiko terjadinya kanker, tumor, dan penyakit katarak, juga membantu kerja pencernaan dan kesehatan organ-organ di sekitar hati serta menghilangkan gangguan anemia (Lintang et al., 2015). Pada selada merah lollo rossa juga memiliki pigmen antosianin yang berguna sebagai penangkal radikal bebas yang merusak sel tubuh (Safii, 2020)

Selain itu, selada yang kaya akan gizi juga banyak digemari oleh masyarakat Indonesia, sehingga permintaan selada dalam negeri meningkat dari tahun ke tahun. Hal tersebut berimplikasi pada meningkatnya pula kebutuhan sayuran bagi masyarakat. Produksi sayuran selada di Indonesia tahun 2015 dan 2016 meningkat sebesar 1.004 ton. Berbeda dengan halnya tahun 2016 - 2017 pertumbuhan produksi sayuran selada meningkat jauh yaitu sebesar 26. 407 ton.(Setiawan, 2012).

Limbah pertanian merupakan sisa dari proses produksi pertanian. Maksud dari sisa proses produksi pertanian adalah seperti hasil triming sayuran dan hasil sortasi. Trimming merupakan suatu proses atau kegiatan pemotongan,penghilangan bagian yang tidak dikehendaki pada tanaman hasil panen. Sortasi sendiri merupakan kegiatan memisahkan hasil pertanian yang layak jual dengan yang tidak layak jual. Salah satu 
pemanfaatan limbah yaitu dapat diolah menjadi pupuk organik, pestisida nabati, ataupun juga menjadi pangan fungsional.

Pemanfaatan pangan fungsional menjadi gaya hidup masyarakat di era sekarang ini, karena masyarakat lebih memilih dan mengkonsumsi makanan yang sehat dan higienis. Pangan fungsional adalah pangan olahan yang mengandung satu atau lebih komponen fungsional yang berdasarkan kajian ilmiah mempunyai fungsi fisiologis tertentu, terbukti tidak membahayakan dan bermanfaat bagi kesehatan (BPOM, 2005). Banyaknya limbah hasil dari trimming dan sortasi dari selada bisa dimanfaatkan menjadi pangan fungsional, yaitu es krim yang disukai oleh semua kalangan. Es krim merupakan makanan yang banyak digemari oleh anak-anak ataupun orang dewasa, oleh sebab itu es krim sangat memungkinkan dijadikan makanan fungsional.

\section{METODE PENELITIAN}

\section{Waktu dan Tempat}

Penelitian dilaksanakan di laboratorium Fakultas Sains Terapan Universitas Suryakancana Cianjur, pada bulan Oktober 2020-September 2021.

\section{Alat dan Bahan}

Bahan yang digunakan dalam penelitian ini di antaranya adalah hasil trimming dan sortasi selada keriting, selada romaine, selada lollo rossa, gula pasir, susu bubuk, santan, garam, susu kental manis, air, tepung maizena, dan emulsifier SP. Untuk alat yang digunakan pada penelitian di antaranya adalah pisau, timbangan, kompor, blender, mixer, box freezer, panci, pengaduk, gelas ukur serta seperangkat alat uji organoleptik.

\section{Tahapan Penelitian}

Pada penelitian ini, dilakukan beberapa tahapan yaitu:

\section{A. Penelitian pendahuluan}

Penelitian pendahuluan ini dilakukan untuk menentukan komposisi bahan tetap dalam proses pembuatan produk es krim dari limbah sayuran selada keriting, lollorossa, dan romaine sehingga diketahui komposisi bahan tetap yang tepat dengan cara menganalisis secara organoleptik dalam segi warna, rasa, tekstur dan aroma. Pada tahap ini, dilakukan dua tahapan yaitu pembuatan pure selada keriting, lollorosa, romaine, dan pembuatan es krim dengan menambahkan pure dari ketiga sayuran tersebut.

\section{Pembuatan pure}

1) Ketiga sayuran dicuci terlebih dahulu.

2) Setelah dicuci kemudian lakukan penimbangan pada ketiga tanaman dengan total $250 \mathrm{~g}$. 
3) Selanjutnya tanaman dipotong kecil-kecil untuk memudahkan ketika diblender.

4) Lalu sayuran yang sudah dipotong kemudian dimasukan ke dalam blender dan tambahkan air sebanyak $300 \mathrm{ml}$.

\section{Pembuatan es krim}

1) Pertama campurkan $100 \mathrm{~g}$ gula pasir, $33 \mathrm{~g}$ susu bubuk, $2 \mathrm{~g}$ garam, $40 \mathrm{~g}$ susu kental manis, dan $250 \mathrm{~g}$ pure lalu diaduk hingga merata.

2) Selanjutnya panaskan adonan tersebut hingga mendidih pada suhu $100^{\circ} \mathrm{C}$. Saat sudah mendidih tuangkan $25 \mathrm{~g}$ tepung maizena lalu aduk hingga mengental dan meletup-letup.

3) Selanjutnya tuangkan adonan ke dalam wadah dan dinginkan sekitar 5 menit dalam suhu kamar.

4) Setelah dingin masukan adonan ke dalam freezer sekitar 6-8 jam.

5) Setelah beku, adonan es krim selanjutnya dihancurkan dengan mixer menggunakan kecepatan tinggi sampai teksturnya halus.

6) Setelah halus kemudian tambahkan $25 \mathrm{~g}$ emulsifier SP, lalu aduk lagi dengan mixer sampai mengembang dengan tekstur seperti whipped cream sekitar 20-30 menit.

7) Setelah selesai di-mixer masukan adonan es krim kedalam wadah yang sudah di siapkan .

8) Terakhir simpan kembali adonan ke dalam freezer.

\section{B. Penelitian utama}

Setelah dilakukan penelitian pendahuluan yaitu membuat eskrim limbah sayuran hidroponik, selanjutnya melakukan penelitian utama yaitu membuat eskrim dari limbah sayuran hidroponik dengan menggunakan pure, prosedur penelitian utama sebagai berikut:

\section{Pembuatan pure}

1) Ketiga sayuran dicuci terlebih dahulu.

2) Kemudian lakukan penimbangan pada ketiga tanaman dengan total $250 \mathrm{~g}$

3) Selanjutnya tanaman dipotong kecil-kecil untuk memudahkan ketika diblender.

4) Lalu sayuran dimasukan ke dalam blender dan tambahkan air $300 \mathrm{ml}$.

\section{Pembuatan eskrim}

Berikut adalah prosedur pembutan es krim yang dilakukan dalam penelitian ini:

1) Pertama campurkan 100 g gula pasir, 33 g susu bubuk, 2 g garam, 40 g susu kental manis, dan $250 \mathrm{~g}$ pure lalu aduk hingga merata.

2) Selanjutnya panaskan adonan tersebut hingga mendidih pada suhu $100^{\circ} \mathrm{C}$. Saat sudah mendidih tuangkan $25 \mathrm{~g}$ tepung maizena lalu aduk hingga mengental dan meletup-letup. 
3) Selanjutnya tuangkan adonan ke dalam wadah dan dinginkan sekitar 5 menit dalam suhu kamar.

4) Setelah dingin masukan adonan ke dalam freezer sekitar 6-8 jam.

5) Setelah beku, adonan es krim selanjutnya dihancurkan dengan mixer menggunakan kecepatan tinggi sampai teksturnya halus.

6) Setelah halus kemudian tambahkan $25 \mathrm{~g}$ emulsifier SP, lalu aduk lagi dengan mixer sampai mengembang dengan tekstur seperti whipped cream sekitar 20-30 menit.

7) Setelah selesai di-mixer pisahkan adonan es krim menjadi 5 sampel.

8) Terakhir simpan kembali adonan ke dalam freezer.

\section{Rancangan Percobaan}

Parameter ini merupakan penelitian eksperimen yang menggunakan parameter uji organoleptik pada es krim hasil samping sayuran selada keriting, lollo rossa, dan romaine yang meliputi rasa, aroma, tekstur, dan warna. Dimana akan melibatkan 24 orang panelis biasa dan 1 panelis ahli. Rancangan penelitian ini menggunakan metode RSM (Response Surface Method), di antaranya dijelaskan pada tabel 1:

Tabel 1. Rancangan percobaan es krim hasil samping tanaman selada keriting, romaine, lollo rossa.

\begin{tabular}{cccc}
\hline \multirow{2}{*}{ Perlakuan } & \multicolumn{3}{c}{ Formula Pure Selada } \\
\cline { 2 - 4 } & Keriting & Lollorosa & Romaine \\
\hline F1 & $70 \%$ & $15 \%$ & $15 \%$ \\
F2 & $15 \%$ & $70 \%$ & $15 \%$ \\
F3 & $15 \%$ & $15 \%$ & $70 \%$ \\
F4 & $60 \%$ & $20 \%$ & $20 \%$ \\
F5 & $30 \%$ & $30 \%$ & $40 \%$ \\
\hline
\end{tabular}

\section{Teknik Pengumpulan Data}

Penelitian ini merupakan penelitian kuantitatif dengan pengujian hedonik yaitu penelitian dengan menganalisis angka-angka yang diperoleh dari hasil penyebaran kuisioner kepada sampel penelitian. Pengambilan sampel dilakukan dengan cara pengumpulan data saat pengisian angket kuisioner dengan pengawasan, sehingga konsumen dalam mengisi akan lebih mudah dan lebih tepat. Data primer dalam penelitian ini diperoleh melalui kuisioner yang diberikan kepada konsumen yang memakan es krim hasil samping selada keriting, lollo rossa, dan romaine yang akan dijadikan es krim. Dimana akan melibatkan 24 orang panelis biasa dan 1panelis ahli

\section{Teknik Analisa Data}

Metode analisis data dalam penelitian ini menggunakan metode RSM (Response Surface Method). Metode yang digunakan yaitu statistika untuk melihat hubungan antara satu atau lebih variabel perlakuan dan metode permukaan respon merupakan suatu himpunan metode-metode matematika yang dilakukan secara berbentuk 
kuantitatif dengan sebuah variabel respon yang bertujuan untuk mengoptimalkan respon tersebut dalam suatu percobaan (Montgomery, 2009 dalam Trihaditia et al., 2018). Dengan tujuh tingkatan Variabel diantaranya 1. Sangat tidak suka sekali, 2. Sangat tidak suka, 3. Tidak suka, 4. Biasa, 5. Suka, 6. Sangat suka, 7. Sangat suka sekali

\section{HASIL DAN PEMBAHASAN}

Pada Bagian ini menjelaskan tentang hasil penelitian dari pengolahan es krim selada keriting (Lactuca sativa L), Romaine (Lactuca sativa var romana), dan lollorosa (Lactuca sativa var lollorosa) dalam berbagai formulasi dengan tujuan sampel manakah yang paling optimal yang disukai oleh panelis. Salah satu metode pengujian yang digunakan untuk mengetahui penerimaan konsumen adalah uji organoleptik. Pengujian orgaoleptik dalam penelitian ini menggunakan uji mutu kesukaan atau uji hedonik. Uji hedonik ini dilakukan pada tanggal 7 Juni 2021, di laboratorium pangan Fakultas Sains Terapan Universitas Suryakancana yang dilakukan terhadap 25 panelis (1 panelis ahli 24 panelis biasa). Pada uji hedonik ini pengukuran berdasarkan parameter warna, rasa, aroma, dan tekstur. Respon panelis terhadap kesukaan sensorik eskrim akan dikonversi dalam bentuk angka sebagai berikut : (1) sangat tidak suka, (2) tidak suka, (3) agak tidak suka, (4) netral, (5) agak suka, (6) suka, (7) sangat suka sekali (Trihaditia et al., 2018).

Hasil dari pengolahan yaitu berupa grafik contour plot yang akan menghasilkan wilayah optimasi yang bergantung pada keragaman respon panelis. Pada wilayah optimasi, ditunjukan dengan skala nilai semakin besar maka semakin kecil wilayah optimasinya yang berarti semakin bagus atau tinggi nilai dari respon tersebut.

\section{Warna}

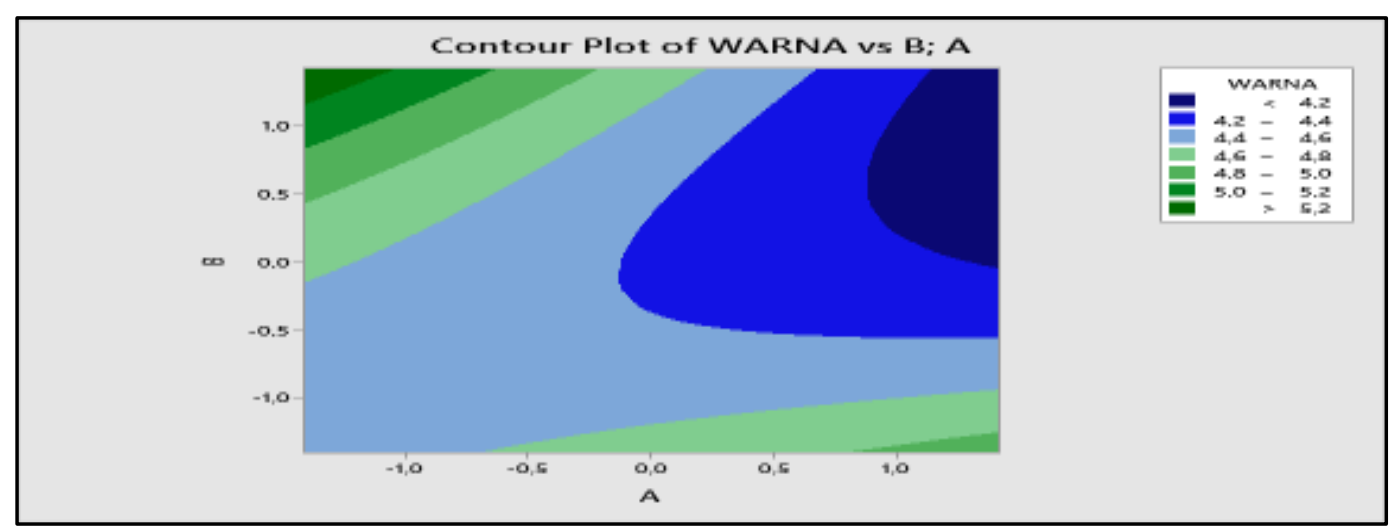

Gambar 1. Contour Plot Warna.

Pada gambar di atas, ditampilkan olahan data respon panelis dalam bentuk contour plot dan dapat diketahui bahwa batasan wilayah untuk nilai optimasi warna 
adalah 4,2 - 5,2. Setelah dilakukan uji organoleptik terhadap parameter warna didapatkan hasil data penelitian yang disajikan pada tabel di bawah ini :

Tabel 2. Skala Optimasi Warna.

\begin{tabular}{cc}
\hline Wilayah Optimasi & Skala Nilai \\
\hline 1 & $>5,2$ \\
2 & $5,0-5,2$ \\
3 & $4,8-5,0$ \\
4 & $4,6-4,8$ \\
5 & $4,4-4,6$ \\
6 & $4,2-4,4$ \\
7 & $<4,2$ \\
\hline
\end{tabular}

Untuk mendapatkan nilai optimal dari berbagai jenis sampel yang digunakan, maka nilai rata-rata sampel tersebut akan dimasukan ke dalam wilayah optimasi, sehingga akan didapatkan nilai optimasi dari sampel tersebut, bisa dilihat pada tabel di bawah ini :

Tabel 3. Nilai Optimasi Warna.

\begin{tabular}{ccc}
\hline Sampel & Rata- rata nilai & Wilayah optimasi \\
\hline F1 & 5,08 & 2 \\
F2 & 3,96 & 7 \\
F3 & 4,52 & 5 \\
F4 & 4,8 & 3 \\
F5 & 4,52 & 5 \\
\hline
\end{tabular}

\section{*Keterangan :}

F1 $=$ Selada keriting 70\% Lollorosa 15\% Romaine 15\%

F2 $=$ Selada keriting 15\% Lollorosa 70\% Romaine 15\%

F3 $=$ Selada keriting 15\% Lollorosa 15\% Romaine 70\%

F4 $=$ Selada keriting 60\% Lollorosa 20\% Romaine 20\%

F5 $=$ Selada keriting 30\% Lollorosa 30\% Romaine 40\%

Dari tabel 3. dapat diambil kesimpulan bahwa sampel F1 merupakan sampel yang disukai oleh panelis dari segi warna, karena sampel F1 berada di wilayah optimasi paling tinggi di antara sampel yang lainnya yaitu 2. Hal ini menunjukan bahwa formulasi yang kandungan selada keritingnya tinggi disukai oleh panelis dalam hal warna. Dilihat dari hasil tersebut, diduga panelis menyukai es krim yang berwarna lebih cerah. Tingkat kecerahan formulasi tersebut dikarenakan formulasi F1 didominasi oleh selada keriting hijau (Lactuca sativa L.) yaitu sebanyak $70 \%$, dimana warna dari selada ini yaitu hijau muda. Perbedaan warna dari setiap tanaman disebabkan jumlah klorofil pada tanaman berbeda-beda, semakin hijau warna daun maka semakin tinggi kandungan klorofilnya (Rahmi, 2013).

Warna dari selada keriting berwarna hijau muda dan warna dari romaine yaitu berwarna hijau sedikit gelap. Adanya pigmen klorofil memberi ciri warna hijau pada daun dan batang tanaman. Pigmen klorofil pada tanaman meliputi klorofil a yang memberi warna hijau tua, dan klorofil b yang memberi warna hijau muda (Widowati, 2012). 
Pada selada merah, daun yang dihasilkan memiliki warna hijau dan semburat warna merah. Kandungan pigmen antosianin tidak lebih besar dari kandungan klorofil, termasuk pada daun yang berwarna merah. Baik pada daun yang berwarna hijau maupun warna merah kandungan antosianinnya lebih rendah dan kandungan klorofilnya lebih tinggi. Hal ini karena klorofil merupakan pigmen utama yang ada pada seluruh tanaman, sehingga meskipun daunnya berwarna merah tidak berarti bahwa daun tersebut memiliki pigmen antosianin yang dominan, tetapi klorofil merupakan pigmen yang dominan (Yanti \& Ngadiani, 2018). Sehingga dapat disimpulkan bahwa panelis menyukai es krim dengan warna hijau muda (F1) dibandingkan dengan warna lain yang ada pada formulasi lainnya.

Rasa

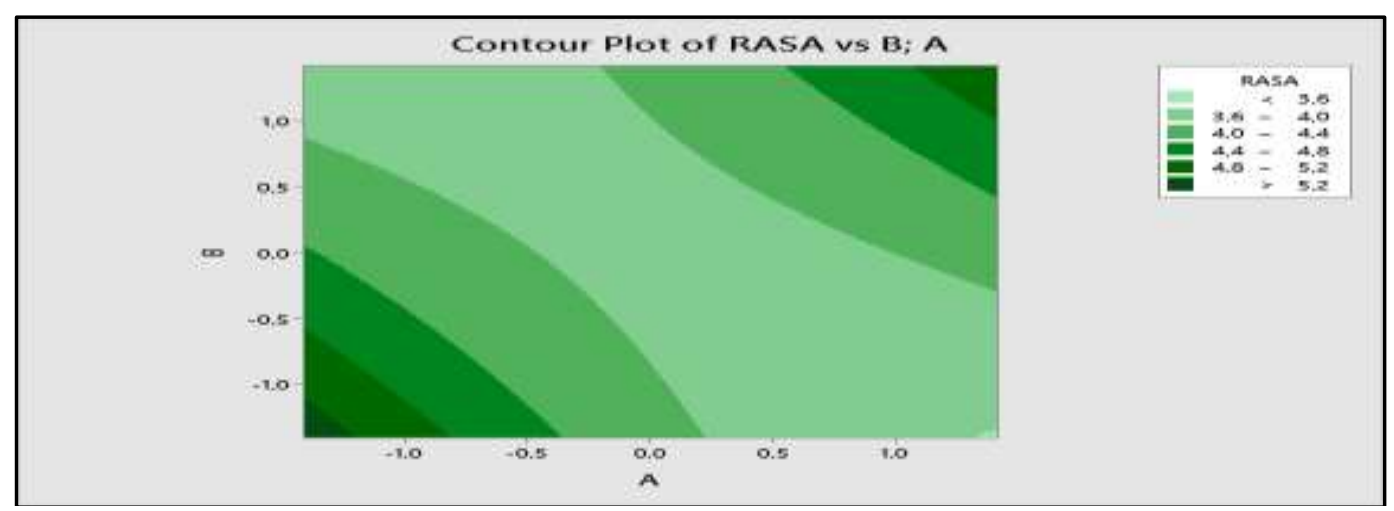

Gambar 2. Contour Plot Rasa.

Pada gambar 3 menunjukkan data dalam bentuk grafik 2 dimensi contour plot, dari grafik tersebut diketahui skala nilai dari 3,6 - 5,2 yang dibagi ke dalam 6 wilayah optimasi nilai rata-rata rasa yang disajikan pada tabel berikut :

Tabel 2. Skala Optimasi Rasa.

\begin{tabular}{cc}
\hline Wilayah Optimasi & Skala Nilai \\
\hline 1 & $>5,2$ \\
2 & $4,8-5,2$ \\
3 & $4,4-4,8$ \\
4 & $4,0-4,4$ \\
5 & $3,6-4,0$ \\
6 & $<3,6$ \\
\hline
\end{tabular}

Tabel 4. menjadi acuan untuk menentukan masuk ke wilayah optimasi berapa nilai rata-rata dari setiap sampel. 
Tabel 5. Nilai Optimasi Rasa.

\begin{tabular}{ccc}
\hline Sampel & Rata- rata nilai & Wilayah optimasi \\
\hline F1 & 4,72 & 3 \\
F2 & 3,84 & 5 \\
F3 & 3,64 & 5 \\
F4 & 4,52 & 3 \\
F5 & 4 & 4 \\
\hline
\end{tabular}

\section{*Keterangan :}

F1 $=$ Selada keriting 70\% Lollorosa 15\% Romaine 15\%

F2 $=$ Selada keriting 15\% Lollorosa 70\% Romaine 15\%

F3 $=$ Selada keriting 15\% Lollorosa 15\% Romaine 70\%

F4 = Selada keriting 60\% Lollorosa 20\% Romaine 20\%

F5 $=$ Selada keriting 30\% Lollorosa 30\% Romaine 40\%

Dari tabel 5. tersebut dapat disimpulkan bahwa F1 merupakan rasa yang paling disukai oleh panelis karena berada dalam wilayah optimasi yang paling kecil dan memiliki nilai rata-rata yang paling tinggi dibanding sampel yang lainnya.

Tanaman lollorosa kaya akan serat dan nutrisi yang bermanfaat bagi tubuh, juga pada tanaman lollorosa memiliki kandungan senyawa metabolit sekunder diantaranya flavonoid, saponin, steroid, triterpenoid, alkaloid, dan tanin (Rohmah et al., 2019). Tanin adalah salah satu golongan senyawa polifenol yang banyak dijumpai pada tanaman (Noer et al., 2018), adanya senyawa tanin dalam bahan makanan dapat menentukan citarasa bahan makanan tersebut. Rasa sepat bahan makanan biasanya disebabkan oleh tanin (Sari et al., 2019). Sedangkan kandungan kimia pada selada keriting yaitu betakaroten, falat, lutein, karotenoid serta senyawa fitokimia seperti fenolik, antosianin, dan asam fenolik. Pada tanaman romaine kandungan kimia yang terdapat di dalamnya yaitu karoten, antosianin, dan fenolik (Ulfah et al., 2019).

\section{Aroma}

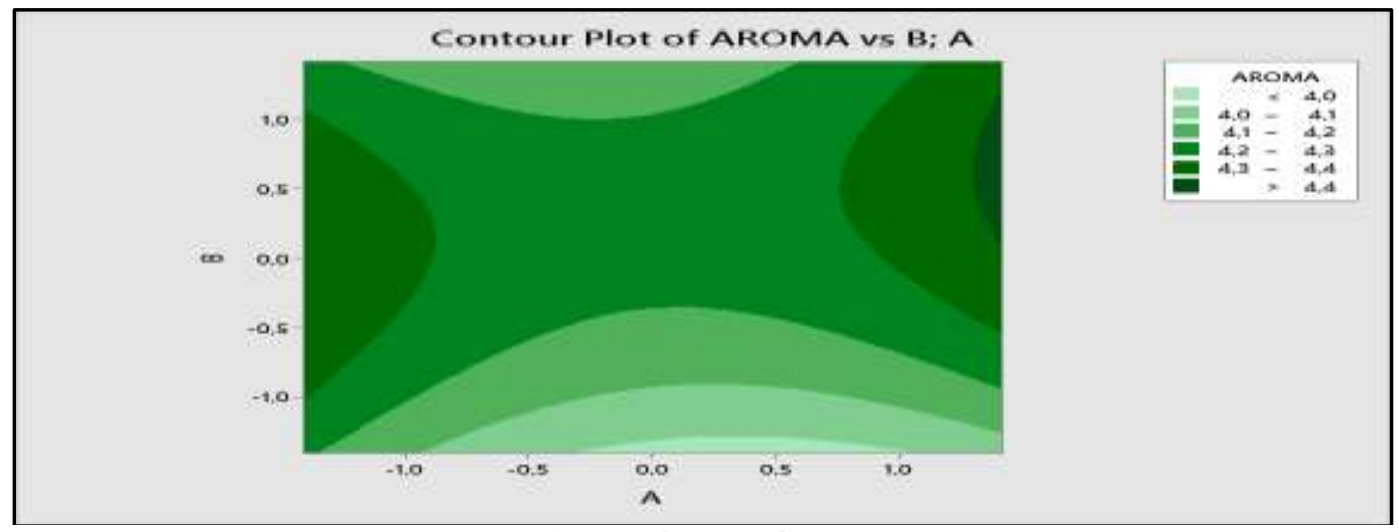

Gambar 3. Contour plot Aroma.

Gambar di atas menunjukkan sajian data dalam bentuk 2 dimensi contour plot, dimana diketahui skala nilai aroma dari 4,0 - 4,4 yang dibagi kedalam 6 wilayah optimasi nilai rata-rata aroma, seperti yang bisa dilihat pada tabel di bawah ini : 
Tabel 6. Skala Optimasi Aroma.

\begin{tabular}{cc}
\hline Wilayah Optimasi & Skala Nilai \\
\hline 1 & $>4,4$ \\
2 & $4,3-4,4$ \\
3 & $4,2-4,3$ \\
4 & $4,1-4,2$ \\
5 & $4,0-4,1$ \\
6 & $<4,0$ \\
\hline
\end{tabular}

Setelah diketahui skala optimasi sebagai acuan, maka diketahui wilayah optimasi nilai rata-rata dari aroma yang disajikan pada tabel 7. di bawah ini :

Tabel 7. Nilai optimasi aroma.

\begin{tabular}{ccc}
\hline Sampel & Rata- rata nilai & Wilayah optimasi \\
\hline F1 & 4,56 & 1 \\
F2 & 4,04 & 5 \\
F3 & 4,04 & 5 \\
F4 & 4,52 & 1 \\
F5 & 4,2 & 3 \\
\hline
\end{tabular}

*Keterangan :

$\mathrm{F} 1=$ Selada keriting 70\% Lollorosa 15\% Romaine 15\%

F2 $=$ Selada keriting 15\% Lollorosa 70\% Romaine 15\%

F3 $=$ Selada keriting 15\% Lollorosa 15\% Romaine 70\%

F4 = Selada keriting 60\% Lollorosa 20\% Romaine 20\%

F5 = Selada keriting 30\% Lollorosa 30\% Romaine 40\%

Dari tabel di atas dapat diketahui bahwa sampel F1 merupakan formulasi yang disukai oleh panelis karena berada di wilayah optimasi yang paling kecil, dan memiliki rata-rata nilai yang paling tinggi dibanding sampel yang lainnya. Nilai tersebut didapat karena diduga panelis menyukai aroma yang tidak terlalu pekat aroma sayuran-nya.

Nilai rata-rata setiap sampel berada pada nilai 4 (Biasa) artinya respon panelis terhadap aroma dari setiap sampel adalah biasa tidak menunjukan bahwa panelis suka atau tidak suka terhadap aroma es krim. Diduga hal ini terjadi karena hilangnya aroma dari setiap sampel karena proses pembekuan. Menurut Suprapto dalam Suprayatmi et.al (2017), proses penghancuran dapat mengurangi aktivitas enzim lipoksidase pada sayur, aroma pada sayur dapat hilang dan menjadi berkurang karena perubahan aktivitas enzim, pengaruh suhu, evaporasi, dan pencucian oleh air.

Menurut Santoso (2011), aroma pada buah dan sayuran terjadi karena adanya sintesis banyak senyawa organik yang bersifat mudah menguap (volatile), senyawa yang bertanggung jawab terhadap aroma buah, sayuran, dan bunga potong merupakan senyawa ester yang mudah menguap. Green leaf volatiles (GLV) merupakan senyawa volatil yang ada pada tanaman sayuran, sehingga hidung manusia cukup peka terhadap aroma yang dikeluarkan oleh tanaman (Ferdian, 2019) 


\section{Tekstur}

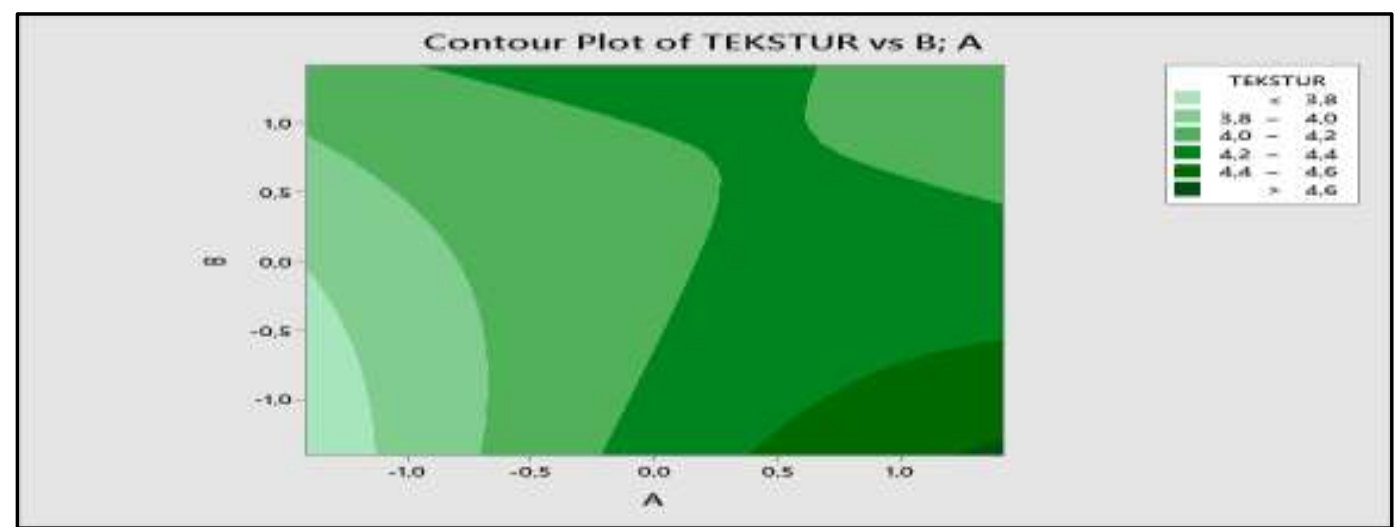

Gambar 4. Contour Plot'Tekstur.

Pada gambar di atas menunjukkan sajian grafik permukaan 2 dimensi contour plot dimana diketahui skala nila tekstur eskrim 3,8 - 4,6 yang dibagi kedalam 6 wilayah optimasi, penelitian ini didasarkan pada pengujian 5 formulasi yang berbeda yang disajikan kepada 25 panelis. Setelah dilakukan uji organoleptik pada parameter tekstur didapatkan hasil data penelitian yang bisa dilihat pada tabel berikut :

Tabel 8. Skala Optimasi Tekstur.

\begin{tabular}{cc}
\hline Wilayah Optimasi & Skala Nilai \\
\hline 1 & $>4,6$ \\
2 & $4,4-4,6$ \\
3 & $4,2-4,4$ \\
4 & $4,0-4,2$ \\
5 & $3,8-4,0$ \\
6 & $<3,8$ \\
\hline
\end{tabular}

Untuk mendapatkan nilai optimal dari berbagai jenis sampel yang digunakan, maka nilai rata-rata dari sampel tersebut dimasukkan ke dalam plot wilayah optimasi, sehingga akan didapatkan nilai optimasi dari berbagai sampel yang disajikan pada tabel di bawah ini :

Tabel 9. Nilai Optimasi Tekstur

\begin{tabular}{ccc}
\hline Sampel & Rata- rata nilai & Wilayah optimasi \\
\hline F1 & 4,68 & 1 \\
F2 & 4,28 & 3 \\
F3 & 3,76 & 6 \\
F4 & 4,44 & 2 \\
F5 & 3,84 & 5 \\
\hline
\end{tabular}

*Keterangan :

$\mathrm{F} 1=$ Selada keriting 70\% Lollorosa 15\% Romaine 15\%

F2 $=$ Selada keriting 15\% Lollorosa 70\% Romaine 15\%

F3 $=$ Selada keriting 15\% Lollorosa 15\% Romaine 70\%

F4 = Selada keriting 60\% Lollorosa 20\% Romaine 20\%

F5 $=$ Selada keriting 30\% Lollorosa 30\% Romaine 40\% 
Pada tabel di atas diketahui bahwa F1 (SK 70\% : LL 15\% : RM 15\%) memiliki nilai optimasi 1, dikarenakan nilai rata-rata sampel tersebut berada di wilayah dengan nilai optimasi 1. Sampel F2 (SK 15\% : LL 70\% : RM 15\%) memiliki nilai optimasi 3, dikarenakan nilai rata-rata sampel tersebut berada dalam wilayah optimasi 3. Sampel F3 (SK 15\% : LL 15\% : RM 70\%) memiliki nilai optimasi 6, dikarenakan sampel tersebut berada di wilayah optimasi 6. Sampel F4 (SK 60\% : LL 20\% : RM 20\%) memiliki nilai optimasi 2, dikarenakan sampel tersebut berada di wilayah optimasi 2. Sampel F5 (SK 30\% : LL 30\% : RM 40\%) memiliki nilai optimasi 5, dikarenakan sampel tersebut berada di wilayah optimasi 5 .

Dari tabel di atas diketahui bahwa F1 merupakan formulasi yang disukai oleh panelis dari segi tekstur, diduga karena memiliki tekstur yang halus. Menurut Tamtarini dan Yuwanti (2005) menyatakan bahwa serat sebagai senyawa yang tidak larut dalam air dan memperkuat jaringan bahan, dalam bahan pangan berfungsi sebagai penguat tekstur. Semakin tinggi kadar serat dalam bahan baku, akan dihasilkan produk dengan tekstur yang lebih kuat dan kokoh sehingga membuat produk menjadi lebih keras.

Menurut Livia E Rantung (2020) selada tanah memiliki batang yang keras dibanding selada hidroponik, faktor yang mempengaruhi kekerasan batang adalah lignin. Kandungan lignin pada tanaman akan meningkat seiring dengan meningkatnya umur tanaman sehingga sel-selnya menjadi kuat dan keras.

Lignin merupakan senyawa kimia yang paling sering berasal dari kayu, dan merupakan bagian integral dari sekunder dinding sel dari tanaman dan beberapa alga. Lignin merupakan bagian terbesar dari selulosa dan merupakan senyawa aromatik, lignin akan mengikat serat selulosa yang kecil menjadi serat-serat yang panjang (Gebrina, 2015).

\section{Penentuan Sampel Terbaik}

Penentuan sampel terbaik dipilih berdasar pada sampel yang paling banyak disukai oleh panelis dalam setiap parameter.

Tabel 10. Penentuan Sampel Terbaik

\begin{tabular}{ccccccccc}
\hline \multirow{2}{*}{ Sampel } & \multicolumn{2}{c}{ Warna } & \multicolumn{2}{c}{ Rasa } & \multicolumn{2}{c}{ Aroma } & \multicolumn{2}{c}{ Tekstur } \\
\cline { 2 - 9 } & Nilai & Optimasi & Nilai & Optimasi Nilai & Optimasi & Nilai & Optimasi \\
\hline F1 & 5,08 & 2 & 4,72 & 3 & 4,56 & 1 & 4,68 & 1 \\
F2 & 3,96 & 7 & 3,84 & 5 & 4,04 & 5 & 4,28 & 3 \\
F3 & 4,52 & 5 & 3,64 & 5 & 4,04 & 5 & 3,76 & 6 \\
F4 & 4,8 & 3 & 4,52 & 3 & 4,52 & 1 & 4,44 & 2 \\
F5 & 4,52 & 5 & 4 & 4 & 4,2 & 3 & 3,84 & 5 \\
\hline
\end{tabular}

*Keterangan :

$\mathrm{F} 1=$ Selada keriting 70\% Lollorosa 15\% Romaine 15\%

F2 $=$ Selada keriting 15\% Lollorosa 70\% Romaine 15\%

F3 $=$ Selada keriting 15\% Lollorosa 15\% Romaine 70\%

F4 $=$ Selada keriting 60\% Lollorosa 20\% Romaine 20\%

F5 $=$ Selada keriting 30\% Lollorosa 30\% Romaine 40\% 
Pada tabel 10., terlihat bahwa formulasi yang ditandai dengan warna kuning merupakan sampel terbaik pada parameternya, dengan kata lain sampel tersebut merupakan sampel paling optimal. Pada parameter warna F1 merupakan yang disukai panelis. Pada parameter rasa F1 merupakan yang disukai panelis. Untuk parameter aroma F1 merupakan formulasi yang disukai panels. Sedangkan untuk parameter tekstur F1 merupakan formulasi yang disukai panelis. Bila dilihat dari tabel tersebut F1 memiliki nilai yang lebih tinggi pada setiap parameternya, sehingga bisa disimpulkan formulasi es krim dengan selada keriting 70\% lollorosa 15\% romaine $15 \%$ merupakan sampel yang disukai panelis.

\section{PENUTUP}

\section{Kesimpulan}

1. Formulasi dari hasil samping selada keriting, lollorosa, dan romaine mempengaruhi karakter organolpetik (warna, rasa, aroma, tekstur). Sampel F1 yaitu dengan formulasi selada keriting $70 \%$ lollorosa $15 \%$ romaine $15 \%$ merupakan sampel terbaik dari kelima sampel yang diuji.

2. Klorofil merupakan pigmen yang mempengaruhi warna pada pembuatan eskrim, karena pigmen klorofil merupakan senyawa yang dominan pada ketiga tanaman. Tanin yang ada pada tanaman lollorosa dapat menyebabkan rasa pahit atau sepat pada es krim sehingga eskrim dengan formulasi lollorosa yang tiggi kurang disukai oleh panelis. Aroma yang khas dikeluarkan oleh ketiga tanaman disebabkan oleh senyawa Green Leaf Volatiles (GLV) yang mudah menguap, sehingga memudahkan panelis mencium aroma. Sedangkan tekstur pada es krim ketiga tanaman dipengaruhi oleh lignin yang terkandung didalam tanaman, karena lignin merupakan senyawa yang memperkuat tekstur bahan pangan.

\section{Saran}

Perlu adanya penelitian lebih lanjut untuk mengoptimalkan tingkat kesukaan panelis terhadap es krim dengan campuran selada keriting, lollorosa, dan romaine diantaranya :

1. Perlu adanya uji coba dengan menggunakan formulasi yang berbeda

2. Perlu adanya diadakan penelitian lanjutan menggunakan bahan lainnya agar eskrim berbahan selada keriting, lollorosa, dan romaine tidak cepat meleleh

\section{DAFTAR PUSTAKA}

BPOM. (2005). Peraturan Kepala BPOM RI Nomor HK 00.05.52.0685. Peraturan Kepala Badan Pengawas Obat dan Makanan Republik Indonesia. 1-13.

Dian, E., Prasmatiwi, F. dan Suryani, A. (2017). Efisiensi Produksi dan Analisis Risiko Budidaya Selada Keriting Hijau dan Selada. Jurnal. 5(3):242-249. 
Ferdian, H. A. (2019). Https://Kumparan.Com/Kumparansains/Kenapa-Rumput-YangBaru-Dipotong-Punya-Aroma-Menyenangkan-1r2pulmtonc/Full.

Https://Kumparan.Com/Kumparansains/Kenapa-Rumput-Yang-BaruDipotong-Punya-Aroma-Menyenangkan-1r2pvlmtonc/Full

Gebrina, Rizki Audina. (2015). Pembuatan Pulp dari Serabut Kelapa Muda Menggunakan Metode Organosol. Tesis. Jurusan Teknik Kimia. Politeknik Negeri Sriwiyaja.

Lintang Aulia, Hadi Ariyantoro, S. H. (2015). Pengaruh Macam Media Tanam dan Konsentrasi Pupuk Daun terhadap Pertumbuhan dan Hasil Tanaman Selada (Lactuca Sativa L.). Innofarm, Jurnal Informasi Pertanian. 14(1):1-11.

Rantung, Livia . E., Lengkey, L. C. C. E., dan Wenur, F. (2020). Analisis Kualitas Selada (Lactuca sativa L.) yang Ditanam pada Dua Media Selama Penyimpanan Dingin. Jurnal Teknologi Pertanian, (Agricultural Technology Journal). 11(1).

Rohmah, J., Rini, C. S. dan Wulandari, F. E. (2019). Aktivitas Sitotoksik Ekstrak Selada Merah (Lactuca Sativa Var. Crispa) pada Berbagai Pelarut Ekstraksi. Jurnal Kimia Riset. 4(1):18.

Sari, D. K., Affandi, D. R. dan Prabawa, S. (2019). Pengaruh Waktu dan Suhu Pengeringan terhadap Karakteristik Teh Daun Tin (Ficus Carica L.) Effect Of Drying Time And Temperature On The Characteristics Of Fig Leaf Tea (Ficus Carica L.). Jurnal Teknologi Hasil Pertanian. 11(2): 68-77.

Setiawan, I. (2012). Usahatani Selada Keriting (Lactuva Sativa L.) Secara Organik di Yayasan Bina Sarana Bakti. Jurnal. 1-9.

Sastradihardja, Singgih . S. (2011). No Title. In Sukses Bertanam Sayuran Secara Organik. Suprayatmi, M; Novidahlia, N ; Ainii, A. (2017). Materi dan Metode Bahan dan Alat Tempat dan Waktu Penelitian Formulasi Ekstrak Rosella dan Kulit Manggis Analisis Produk. Jurnal. 8(2): 98-105.

Tamtarini dan Yuwanti, S. (2005). Pengaruh Penambahan Koro-Koroan terhadap Sifat Fisik dan Sensorik Flake Ubi Jalar. Jurnal. 187-192.

Tunjung. (2010). Analisis Efisiensi Pengelolaan Persediaan Bahan Baku Kedelai Perusahaan Kecap PT. Lombok Gandaria Food Industry Pelur Karanganyar. $1-92$.

Ulfah, M., Putro, A. L., \& Safitri, E. E. (2019). Uji Aktivitas Antioksi dan Ekstrak Etanol Daun Selada Romaine (Lactuca Sativa Var. Longifolia) dan Daun Selada Keriting (Lactuca Sativa Var. Crispa) Beserta Identifikasi Beberapa Senyawa Antioksidan. Jurnal Ilmu Farmasi Dan Farmasi Klinik. 16(01):21. 